\title{
"A WOMAN WAITS FOR ME": ANNE GILCHRIST'S READING OF LEAVES OF GRASS
}

\author{
Steve Marsden
}

I draw you closer to me, you women,

I cannot let you go, I would do you good,

I am for you, and you are for me, not only for our own sake, but for others' sakes,

Enveloped in you sleep greater heroes and bards,

They refuse to awake at the touch of any man but me.

-Walt Whitman, "A Woman Waits for Me"

THE STORY OF THE CURIOUS COURTSHIP of the poet Walt Whitman by Anne Gilchrist is already well known. This most extraordinary romance has been recounted in some detail, from a number of viewpoints, in a variety of sources, biographical and critical. ${ }^{1}$ There is another story here, even more remarkable. It can open up for us the complex of issues that confront any student of Whitman's poetry-the intersection of interpretation and fantasy, sex and religion, author and reader. It can help us understand how a strong reader can realize on the page not just an image of the author, but a new image of herself. It is the story of not just a remarkable love, but of a remarkable reading.

When Anne Gilchrist first read William Michael Rossetti's selection of poems from Leaves of Grass, she was forty-one, the mother of four children, and the widow of Alexander Gilchrist, a biographer and art critic. She was a woman of not inconsiderable accomplishments. She had assisted throughout the composition of her husband's monumental biography of William Blake, and, following his unexpected death from scarlet fever, had seen the manuscript through the difficult process of completion, revision, fact-checking, and printing. Later, she published several articles of her own that explained current scientific theories and discoveries to a general magazine audience. The couple maintained close friendships with some of the foremost British literary and artistic figures of the day, including Tennyson and the Rossettis, and amiable acquaintance with still more. Though possessing a strong instinct for intellectual independence and a deep commonsense rejection of empty conventionality, Anne was a devoted mother who had temporarily sacrificed the literary goals that were so important to her in order 
to raise her children as a single parent. Hers was a life that demanded intellectual work and direction. In an 1863 letter, Anne calls the Blake biography, which she had recently completed, her "beloved task" which had "kept [her] head above water in the deep sea of affliction" after her husband's death. "Now that it is ended," she writes, "I sometimes feel like to sink - to sink that is, into pining discontent-and a relaxing of the hold upon all high aims. I find it so hard to get on at anything beyond the inevitable daily routine, deprived of that beloved and genial Presence, which so benignantly and tenderly fostered all good, strengthening the hands, cheering the heart, quickening the intellect even."2 During such a becalmed and discontented period, Anne Gilchrist made the acquaintance of Walt Whitman: first the Walt Whitman who projected himself so strongly from the poems in Rossetti's selection, then, months later, the Walt Whitman manifested more completely in the unexpurgated 1867 edition of Leaves of Grass lent to her by Rossetti himself.

This chance meeting led to a love-affair of sorts between the brilliant, lonely, progressive Englishwoman, and the book which was, it insisted, not just a book, but a man. Like most remarkable love-affairs, it involved mind, body, and soul, past hopes and future dreams, and left everything changed in its wake. We could speak of it as an intellectual revolution, a spiritual illumination, a physical arousal, a personal passion. In this case, it might be sophistry to attempt to separate them. Whitman wrote often of his readers as latencies, potentials activated, "thrilled" in sympathy with his work. That work certainly acted as a catalyst in the life of Anne Gilchrist-allowing her to realize, after a lengthy dormant period, tendencies that had been long in developing, with roots that stretched deep into her past.

Most accounts of this remarkable relationship focus on the final disparity between the virile, vigorous, all-accepting Whitman projected from the book and the flesh-and-blood Whitman whom Gilchrist would eventually meet - old, generally infirm, largely disabled by his stroke of 1873, and (as critics have become increasingly aware throughout the twentieth century) uninterested in conventionally romantic relations with women. ${ }^{3}$ E. H. Miller summed up the prevailing critical response to the correspondence between Whitman and Gilchrist ("the most extraordinary . . . in the language," as Miller calls the letters) and the first meeting between the two in 1876 . He calls the correspondence "an amazing spectacle, the stuff of tragedy for some writers, of comedy to others."4 But Anne Gilchrist, and her relationship with Whitman, has since received a more sympathetic and considered reevaluation. ${ }^{5}$ Paul Ferlazzo pointed out that "What caused such a total response to the man, was the total response of Mrs. Gilchrist to his poetry. She understood the poetry, as Whitman himself had admitted, 'better and fuller and clearer 
than anyone else." " ${ }^{\prime \prime}$ Most recently, Suzanne Ashworth has analyzed the rhetoric of Gilchrist's letters in the context of Victorian women's epistolary writing, bringing to bear the specific conventions that inform the exchange between Gilchrist and Whitman. ${ }^{7}$

In her biography of Gilchrist, Marion Walker Alcaro dismisses some of the more conventionally tragic or romantic narratives that had been imposed on the relationship. Alcaro opens up the study of Gilchrist as a strong figure in her own right. While some earlier critics paint Gilchrist as a hapless or ridiculous figure in the grip of a delusion, Alcaro emphasizes the poise, graciousness, and inner courage with which Gilchrist accepted, after she had crossed the ocean to be closer to Whitman, that her dreams of romantic union were not going to be fulfilled. Despite earlier narratives that emphasized Gilchrist's disillusion and despondency after meeting the poet, Alcaro shows that Gilchrist in fact engaged in a close, loving friendship with Whitman that was no less intimate for not being romantic, and lasted for the rest of her life.

For the purposes of this account, however, I wish to focus not on the way in which Gilchrist lost the fever of her initial response to Whitman's book and became such a valuable and intimate friend of Whitman the man. Neither will I focus on the way that Gilchrist's early letters about Whitman, published as "A Woman's Estimate of Walt Whitman" served to bolster Whitman's reputation when it was in considerable need of reinforcement. ${ }^{8}$ Instead, I want to explore the details of that first burning enthusiasm that awakened Gilchrist from years of a life that, though "busy \& content, practical, earnest," had been deadening to her intellect, stifling to her spirit, and repressive to body and heart. ${ }^{9}$ Conversion is not precisely the right word, but perhaps no other will do so well. The change triggered by her interaction with Whitman's book, which Gilchrist called a "new birth," gave her hope for the future (her personal future, that of women in general, and that of humanity), brought her across the Atlantic, and gave her the impetus to resume a project of philosophical, religious, and literary inquiry that she had put aside in favor of domestic duties (Letters, 59). Romance is too light a word for this sort of reading. It involves, and any explanation of it must call upon, not only a text and a need, but the whole history of the life that the encounter invoked and reoriented: habits of mind and reading, webs of belief and inquiry.

\section{Reading before Whitman}

In order to understand Gilchrist's remarkable response to Whitman's writing, we must first explore her early education and the model of reading she developed before her encounter with Leaves of Grass. In the very first letter that is preserved from the then Annie Bur- 
rows, we find her a schoolgirl of seventeen and an avid reader. She already sometimes preferred the depth of literary experience to the relative poverty of first-hand encounters. She was guilty, that is, of what Whitman might have called looking "through the eyes of the dead" or feeding "on the specters in books." In this letter to a school friend, she ponders the possibility of travel to see the great vistas of Europe, but decides that she prefers instead to read descriptions of scenery by her favorite authors because, "You see it, as it were, through the medium of their brilliant imaginations, and a tide of interesting, of beautiful associations, invest it with a thousand charms, which, if I gazed on it myself, my dull intellect would fail to supply" $(A G, 23)$.

In fact, her intellect was hardly dull. Anne's formal schooling had been tolerable by the standards of female education of the time. Until the age of seventeen, she received from "the misses Cahusac's" (proprietors of an evangelical school for girls at Highgate) rather more than the usual narrow course of deportment and "accomplishments": picking up not only how to walk prettily and play the piano, but "at least a modicum of instruction in mathematics, literature, possibly history, and probably French" (Alcaro, 37). She was a brilliant student from the start and showed extraordinary powers of recall. A school friend recalls that when Anne was called on to memorize the contents of a page, she was not only able to complete the exercise perfectly, but could still repeat the page verbatim some twenty years later $(A G, 20)$.

Given the choice, she always preferred reading to needlework (that most common and often most despised of nineteenth-century middleclass women's labors). The girls of the school were required to sew for two hours a week "for the poor ... a task which was enlivened with reading aloud" $(A G, 21)$. When the governess asked who would like to do the reading, Anne always spoke up-and on those occasions when she was kept from reading, she kept to a simple stitch, to keep her mind free. In the ninteenth century, this kind of communal reading during labor was not an uncommon entertainment. There's no way to know what Anne read aloud to the other girls, though we may be sure the books were carefully chosen for their improving character.

The bulk of Anne's real education was owing to an impressive selfimposed program of reading in science, literature, and philosophy. We see evidence in her letters of 1848 of reading in what she considered the "opposite poles" of mysticism and materialism (poles she would later attempt to reconcile). She explains that she is studying "Emerson, as a sort of balance to my usual studies in Comte" $(A G, 29)$. She writes that "Emerson's writings are treated with a good deal of contempt and ridicule now, but I think the next generation will call him a great man." All that was lacking was "the patience to study him, in spite of his apparent affectation and mysticism." 
Patience was something the largely self-educating Anne Gilchrist had a great deal of. Like Richard Maurice Bucke and other readers who fell most enthusiastically under the spell of Whitman's poetry, she also had an independent and unconventional habit of reading, staying current with modern scientific thought and pursuing new ideas without timidity (readers of less liberal and less flexible habits could hardly be expected to embrace Whitman's style or his message, and few did). As a reader, we might say, Gilchrist was something of an explorer, continually widening her sphere of sympathy, reading to be challenged, to grow and change.

In the most revealing moments from her biography, we often see her with a book. Once, young Anne was reading Rousseau's Confessions in Highgate cemetery, near her school. Absorbed in the book, she scarcely noticed when a local vicar accosted her. When the vicar enquired as to the title of her book, she responded truthfully, but "almost inaudibly ... the last word only caught the parson's ear." The confused vicar assumed she meant St. Augustine's Confessions, and responded "Ah! Good reading; a very good book, my dear" $(A G, 22)$. She did not trouble herself to correct him. She shows herself in this incident, as elsewhere, fearless, independent, but always tactful.

This attitude extended to her religious opinions. One of the friends of her youth noted that at the age of fifteen Anne had already begun to show "a love of freedom of herself in theology . . . combined [with] an anxiety not to unnecessarily shock those who thought orthodoxy essential" $(A G, 21)$. When, in 1848 , a school friend expressed concern over Anne's unorthodoxy, Anne replied that although she felt gratified by "the warm, true affection" which caused the concern, she worried that "such anxiety betrays a want of confidence in the power of truth and in the goodness of God. Can you believe that one who earnestly and humbly seeks the truth, will be permitted to embrace vital error?" $(A G, 25)$. This mixture of belief in the vital importance of free inquiry with a final faith in the goodness of the universe would later enable her to accept Whitman's radical but optimistic faith as what William James might have called a "live option" - a belief system that it was possible for her to accept. Also in this early letter, Gilchrist plays down the importance of religion as rule or dogma, in favor of a conception of religion as a profound experience that unfolds over time. Creeds and doctrines are "mere definitions . . . calculated to circumscribe truth, and bring it down to the narrow level of our half-awakened understandings, [rather] than to raise our minds to deep, elevated, life-giving comprehension of it." This comprehension is not "bestowed upon us at once by the Creator but is to be earned slowly, by years of labour" $(A G, 25)$.

An outward show of faith was not adequate for Anne. A belief in God, she wrote, is "not lightly to be professed, but rather humbly to be 
sought; not to be found at the end of any syllogism, but in the inmost fountains of purity and affection." Belief is "not the sudden gift of intellect, but to be earned by a loving and brave life." It is, however, "the greatest thing allowed to mankind, the germ of every lesser greatness. . . . The soul pants to worship God. Could it but catch a glimpse of its Creator, it would at once be filled with awe and deep humility, with love to man, with divine energy, and with the thirst for perfection" ( $A G, 25-$ 26). Finally, she shows her sympathy with Romantic and Transcendentalist writers by emphasizing religious experience in life and development of the potentials of the individual human self rather than some hypothesized reward after death $(A G, 26-27)$.

In a later letter to the same friend, Anne professes another trait that might be called typically Emersonian - a deep eclecticism in her reading, and a belief in the necessary role of a sympathetic reader to glean the fragments of a greater truth out of diverse sources. "After all," she writes, "eclecticism is a fine thing. Truth is to be found complete in no man's system, but a portion of it in all systems. It is for the reader to collect it, and reconcile apparent contradictions" ( $A G, 29-30)$.

Reading for Gilchrist was never passive or unaffecting, never a matter of reception without corresponding action. Years later, after the death of her husband, Anne writes to her friend William Haines, defending her choice to continue writing scientific articles "in the teeth of all my difficulties and limitations within and without, of time and opportunity and ability." She must continue to try to write, she says, "else I should slowly gravitate downwards into entire absorption in busy, bustling, contriving working-day material life" $(A G, 151)$. "For after all," she continues, "when youth and growing time are left behind and ripening time comes - if there be anything to ripen - reading is not enough. Prose reading becomes either oppressive or useless unless the mind rouses itself to take a more active part than that of being the bucket pumped into." Reading calls for work in response; both work and response have spiritual value in the development of the self; and the best reading rouses the mind to its own activity.

Like so many spiritual questers of the time (Whitman included), Anne Gilchrist was attempting on her own to reconcile an imperative to religious faith, a need to view the world as sacramental or mysterious, and the intellectual demands of the discourse of science. ${ }^{12}$ Her philosophical position by the late 1860's was an attitude she called "materialist" but which emphasized an underlying and immortal informing force in all things. Walking with Tennyson in the countryside, she had a conversation on the subject, which she notes in a letter to a friend:

I ventured to say that [materialism] was a term of reproach chiefly because people had so inadequate and false an idea of matter, that matter was wholly a manifestation of 
force and power; he agreed . . . then added, 'You mean that we have a little bit of God in the middle of us;' to which I cordially assented. $(A G, 170)$

When Tennyson argued that arguing about "immortality and such topics" was futile, as it was "wholly a matter of instinct," Gilchrist answered that "conservation of Force went a great way toward actual proof." The law of conservation of force which she offered Tennyson as possible proof of (or indication of) immortality had been the subject of the last and longest of her several scientific articles, "The Indestructibility of Force," which had appeared in Macmillan's Magazine in 1862.

In the article, Gilchrist attempts to show that scientific discoveries do not threaten religion or poetry, but that the discourses, rightly conceived, should work together. The idea of "immortality" only appears to be threatened by the discovery of a universe where nothing stayswhere "rivers do not flow on for ever: between the granite rock and the cloud it is but a question of time."13 Gilchrist searches for the eternal within a world of change, and finds it in the idea of the interchangeability and indestructibility of force. She quotes Faraday to the effect that all forces are traceable into "one common origin," all "manifestations of one fundamental 'Power"' (Gilchrist, "Indestructibility," 342). Speculation as to a further unity, the "mysterious and indissoluble connexion, perhaps identity ... . between matter and force" may, she writes, be in vain. However it is a

gain worth all the toil to recognize vividly that there $i$ a deep mystery not only in that which lives and grows, but in the very stocks and stones. No longer mistaking our own shallow conceptions for complete and absolute truth, our minds become as a clear unclouded mirror, where in dim and shadowed grandeur some suggestions of this far-off absolute truth will perhaps be reflected. (Gilchrist, "Indestructibility," 344)

If the subject here is scientific, the language is mystical.

As Gilchrist wrote years earlier, the reader's job is to "reconcile apparent contradictions." In the second half of the nineteenth century, after the groundbreaking works of geology and evolutionary biology had set up a view of the earth's history quite contrary to that found in the book of Genesis, science and religion were producing contradictions. But these apparent contradictions form a dialectic motion towards wisdom, if embraced. If scientific discoveries appear to contradict what are held to be "high and sacred truth," she writes, "we may rest calmly assured that a fuller knowledge of such facts, a deeper insight into their true bearings, will dispel the appearance of antagonism." A forwardlooking faith is necessary - to "go boldly on to reach this higher stage, not turn back and basely seek the dark shelter of ignorance."

Romantic nostalgia, with its longing for a more innocent time or some hypothesized golden age, was clearly not an option for Anne 
Gilchrist. At the end of the article, she turns to poetry, attacking its "tone, not of open hostility, but of covert contempt for science." She quotes Wordsworth's "memorably unjust lines" that scientists would "Peep and botanize upon their mother's grave." The beauty and mystery of the physical world, she protests, "are not of such flimsy, shallow kind, as to vanish beneath an earnest questioning gaze." The answer is to "exalt and spiritualize our idea of matter, and, far from destroying, to enhance our sense of mystery." Gilchrist shares with Whitman and Emerson the conviction that scientific inquiry would not remove the wonder at or our sacramental consciousness of the material world-it would deepen them, and extend our knowledge of the divine.

This thoroughgoing refusal of nostalgia and this forward-looking attitude are, Gilchrist implies, traits she shares with a larger female readership. She writes to William Michael Rossetti in 1870 about her distaste for literature that looks back towards an idealized past (in this case, Swinburne). She argues that most women readers are unenthusiastic at best about backwards-looking literature "owing to the subtle but deep and real sense they have of the starved and barren heritage in life of woman in that old world" $(A G, 195)$. For women, she is convinced, "To-day is but the dawning time" and "hints of an undreamed of beauty and greatness just beginning to disclose themselves, by and by to unfold into a Life Poem that will beggar all words" $(A G, 195)$. Anne has already by this time adopted as congenial to her own views Whitman's idea of life itself as poetry, an enacted poetry equal to or more important than poetry that consists of words on the page. Later, in a letter to Whitman explaining why women should take part, not just in needlework, but in the "rough bodily work" needed in maintaining a household, she compares "the Poem Nature . . made up half of rude, rough realities and homely materials \& processes" with the "Poem, Home," to which women must put their own hands, else "their Poem will lack the vital, fresh, growing, nature-like quality that alone endures, and that of this soul will grow, with fitting preparation \& culture, noble \& more vigorous intellectual life in women, fit to embody itself in wider spheres afterwards-if the call comes" (Letters, 110). ${ }^{14}$

Domestic work is for Gilchrist (at least after reading Whitman) both a sort of gymnastics and a form of self-expression. Instead of rejecting the role of domestic helpmeet, of "angel in the house," Gilchrist personalizes it and makes the role something heroic and forward-looking, making herself by analogy a poet (the author of a "life-poem") shaping the development of her children and herself. ${ }^{15}$ By all accounts, Gilchrist herself was a canny and practical master of domestic matters. In 1865 she wrote an article, "A Neglected Art," in which Gilchrist treats the mastery of traditional domestic tasks via "masculine efficiency 
and thoroughness" as a precondition or a first step towards seeking a wider role for women. ${ }^{16}$

Searching for types, the finding of shadows of later events in former ones, is an important practice not only in theology but in attempting to understand a life. Prior loves, as prior books, leave one with expectations, empty shapes into which later lovers and literary experience will fit. Anne Gilchrist's work with her husband on the Blake biography, it seems likely, provided not one but two "gaps" that later would seem to adumbrate the coming of Whitman into her life. From Blake (or any number of the Romantics who flavored the intellectual atmosphere in which she lived and grew), she adopted the idea of a poet as prophet, as mystic, as creator (or would-be creator) of national myth, and of literature as the proper vehicle for social and personal change. At the same time, through her marriage to Alexander Gilchrist (as often from its deficiencies as from its strong points), she was building a model of a kind of relationship that she would later "recognize" in Leaves of Grass and which she would offer to Walt Whitman.

In an 1848 letter to her friend Julia Newton, the future Mrs. Gilchrist (writing in the third person) announces her engagement to Alexander. She describes the young writer as "one who can fulfil her aspirations, realize her ideal of a true marriage, one who is her friend and helper, as well as her lover" $(A G, 30)$. He is, she writes, "altogether, both in intellect and heart, great, noble, and beautiful." However, by the time, almost twenty years later, of her first private letters to Walt Whitman, Anne would tell a different story of the relationship and its aftermath, one that she would call "a death struggle."

Alexander Gilchrist asked Anne to marry him three times. The first time, she said she "liked him well as my friend, but could not love him as a wife should love \& felt deeply convinced that I never should" (Letters, 158). Alexander "was not turned aside, but went on the same as if that conversation had never passed." A year later, he asked again, and Anne, "deeply moved by and grateful for his steady love, and so sorry for him," assented. "But next day, terrified at what I had done and painfully conscious of the dreary absence from my heart of any faintest gleam of true, tender, wifely love" she said no again. He asked once more, a few months later, and the third time was successful-in a way. Anne's reaction was hardly romantic, in a conventional sense. "I prayed very earnestly," she writes,

and it seemed to me that I should continue to mar \& thwart his life so was not right, if he was content to accept what I could give. I knew I could lead a good and wholesome life beside him - his aims were noble - his heart a deep, beautiful, true Poet's heart; but he had not the Poet's great brain. His path was a very arduous one, and I knew I could smooth it for him — cheer him along it. It seemed to me God's will that I should marry 
him. So I told him the whole truth, and he said that he would rather have me on those terms than not have me at all. (Letters, 58-59)

Her aspirations all along, it seems, were literary, intellectual, and spiritual. The path she chooses here after much introspection is to be an encourager and help-meet. This was a role she would serve for her other literary friends and later offer to Whitman. Looking back, however, she sees that, despite their uneven arrangement, Alexander had the better part of the relationship:

He said to me many times "Ah, Annie, it is not you who are so loved that is rich; it is I who so love." And I knew this was true, felt as if my nature were poor \& barren beside his. But it was not so, it was only slumbering-undeveloped. For, my dear Friend, my soul was so passionately aspiring -it so thirsted \& pined for light, it had not the power to reach alone and he could not help me on my way. (Letters, 59)

What Anne Gilchrist called "the reward and crown of the day" was shared reading. Alexander would read aloud "earnest books" to Anne, who was "working (with the needle) the while" $(A G, 36)$. She then "'read' music to him." Anne's account of this scene of domestic bliss contains a catalogue of the books they had read together.

Anne reports that Herbert Spencer's then newly published Social Statics "has taken great hold of us." In this influential volume, Spencer argues for the inevitable progress of humankind towards an ideal moral state. This evolution of society, however, is contingent on the exercise of human freedom of action, thought, and speech. Spencer argues that human happiness only comes from free exercise of the faculties of the individual, and that "the exercise of the faculties is God's will and man's duty." ${ }^{17} \mathrm{He}$ calls for sweeping reforms including universal suffrage and equal rights for women, and suggests that the relationship between the sexes must change too, marriage rapidly evolving towards an ideal of mutual concession, where "self-sacrifice will be the ruling principle" on both sides and "Committing a trespass will be the thing feared, and not the being trespassed against." This change will result, Spencer argues, in a "higher harmony than any we yet know" (Spencer, 150).

The couple also read Elizabeth Barrett Browning, which Anne said elevated her "notion of women's capabilities in verse," and Carlyle's Life of Sterling, about which she gushes in what appears to be a sort of literary crush:

[I] $t$ is a book to vivify one's very heart, revealing as it does the tender, gentle, beautiful, loving, and lovable nature of him (Carlyle), the great, stern, earnest thinker, before whose burning intensity, like that of an old Hebrew prophet, as it has been said, we almost tremble. Surely never before was there in any man the union of such Titan strength and keenest insight, with soft, tenderest, pitying gentleness. Never surely a 
man who so had the power of winning deep, reverent heart's love from his readers. ( $A G$, 36-37)

Gilchrist's reaction to Carlyle foreshadows her much more intense and lasting response to Whitman. ${ }^{18}$ She shows a well-developed tendency here to extrapolate an image of an author from his work and to enter into emotional sympathy with that image.

By the time Alexander Gilchrist died - carried off unexpectedly by a bout of scarlet fever-Anne Gilchrist had developed ideas about relationships that owed a debt to Emerson's views of friendship and Spencer's progressive social theories. These ideas focused on the ability of the friend to facilitate an individual's spiritual and moral development. If Anne's reaction to Whitman proved extreme, it is because in him she saw someone who, unlike poor Alexander, had both the heart and the brain of a great poet, someone who seemed more suited than any to further her spiritual development: a potential lover and a sort of guru or spiritual guide combined. Yet the poet as she saw him, plagued by misreading and vilified by many critics, and later suffering from the effects of his stroke, also inspired her to a role of selfless help-meet. It was a role she had often played.

Horace E. Scudder, who had met Anne in Boston, ${ }^{19}$ wrote in a brief essay that she was "always herself, but then her self was a nature which obeyed the great paradoxical law of finding life through the loss of it." ${ }^{20}$ This tendency to self-sacrifice, shown best in her marriage to a man with whom she was not entirely in love, showed itself throughout her life in other places. In 1867, she supervised the furnishing and repairs at Grayshott, a house near her residence that the Tennysons had let, writing in a letter that she had "put my hero worship into a very practical shape this winter" $(A G, 165)$. Her literary friends and her own family alike received Anne's unstinting labor.

\section{Reading Whitman}

To understand the effect that Leaves of Grass had on Anne Gilchrist, we must understand how she read it. Like many of the other "Whitmaniacs," Gilchrist took Whitman's claims for the effects of his book and his instructions on how it was to be read quite seriously. She understood as well as any of his early critics the way in which Whitman's poems provided their own interpretive structure and context. Paul Ferlazzo argues that Gilchrist has "a perception and poetic understanding unmatched" in her time "in sensitivity and accuracy." 21 That perception and understanding are put to work not in judging Whitman's work against an external standard, but in the service of reading Whitman as she thinks he wishes to be read. To many, Gilchrist's reactions to 
Whitman's work will seem uncritical, and they are. However, Gilchrist's lack of critical distance and her rejection of a conventionally "literary" interpretive framework may prove just how acute a reader of Whitman she was. Whitman more than most poets attempted to provide a set of procedures for reading his work, attempting to abolish distance and distinction between the reader, the author, and the book, and Gilchrist responded to that attempt with an unusually keen receptivity.

First and perhaps most important, Gilchrist did not read Whitman inside the frame of "literature," narrowly construed. John Burroughs, one of Whitman's first disciples, had earlier proposed that Whitman's acceptance would require a change in the criteria applied to poetry. ${ }^{22}$ Throughout his career Whitman had tried to effect this change to a more Emersonian conception of the role-of the poet not as litterateur merely, but as representative man, effusing his influence through culture and history. The later disciples all recognized the need for this change, and each attempted to put it into practice. Like Bucke, Edward Carpenter, and the Bolton Whitmanites, Anne Gilchrist considered Whitman's chief area of influence to be in the area of religion. The poet provides a new religious model, a new consciousness of the universe which in time would eventually revolutionize society and human relations. She writes in an 1870 letter to William Michael Rossetti, "Whitman is, I believe, far more closely akin to Christ than to either Homer or Shakspeare or any other poet" $(A G, 203)$. She backs up this extraordinary confidence by paraphrasing Whitman's 1855 preface in her letter: "I may say this to you, because I know you hold with me, that 'the whole theory of the supernatural departs as a dream.' And this is what I meant when I said 'Poetry must accept him, \&c. or stand aside'" ( $A G$, 203-204).

For both Gilchrist and (she assumes) Rossetti, ${ }^{23}$ the religious and the poetic are not entirely separate or separable fields. In her letter Anne closes the spheres still further. She can write of the parallels between Whitman and Christ, but obviously not because she believes Whitman to be a supernatural figure. As we have seen and will see, the supernatural is not a valid category for her at all-all the action, no matter how rare or extraordinary, of the soul, mind, and the body are compact and conceived of as natural. Instead, she believes Christ, as the originator of a vast current of thought and feeling, to be the greatest sort of poet:

Surely we must regard as 'greatest, divinest,' those human suns who send out their waves of light and impulse through the longest and widest stretches of time and space, vitalizing most germs; kindling and vivifying most hearts and brains? If the poet type is still to be accepted as the highest type (as I think it will) the boundaries must be enlarged to include Christ who never wrote a line: it must be entirely a question of the thing uttered and not at all of the 'the mode of utterance;' and many names that have stood very high on the roll must go down to the rank of 'sweet singers' only. $(A G, 204)$ 
In making this classification, Gilchrist borrows directly from Whitman's own distinction between poet and "singer," developed most explicitly in "The Indications" (later called "Song of the Answerer"). Whitman writes that "The singers do not beget-only the POET begets" ( $L G$ $1867,313)$. The "maker of poems," the poet in the greater sense that Gilchrist uses here, "settles justice, reality, immortality, / His insight and power encircle things and the human race, / He is the glory and extract, thus far, of things, and the human race." Message and reception-the originality, scope, and fitness for the future of what is said, and how deeply the poet's words touch and create a world for his or her audience - are to be considered more important than matters of poetic form in judging who is a poet in this larger sense.

She felt a kinship between Christ and Whitman earlier than this, if we are to trust an account of her given by Edward Carpenter. He writes in his Days with Walt Whitman that Gilchrist told him several times how, when opening for the first time "the volume [of the Rossetti selection], ... her eye fell upon the fine nearly full-length engraving (taken from a daguerrotype [sic]) of the author, she exclaimed: 'Here at last is the face of Christ, which the painters have so long sought for'; she always maintained that the reading of the book itself did but confirm and deepen that first impression." 24 The image which Gilchrist had identified Whitman's image as Christ's was a smaller re-engraved version (head and chest only) of the famous composite engraving that had formed the frontispiece of the 1855 edition. ${ }^{25}$

The force of Whitman's words to remake a world and induce something like a religious conversion or a revolution in consciousness was something Gilchrist herself had felt. In her letters to Whitman, she gives an account of her experience of reading in explicitly religious terms. Writing about a section of Leaves of Grass she tells Whitman, "I respond to that as one to whom it means the life of her Soul. It comforts me very much" (Letters, 83). Gilchrist finds in Whitman's own account of writing Leaves a justification for the life-changing power that the book has had over her:

You speak in the Preface of the imperious \& resistless command from within out of which "Leaves of Grass" issued. This carried with it no doubt the secret of a corresponding resistless power over the reader wholly unprecedented, unapproached in literature, as I believe, \& to be compared only with that of Christ. ${ }^{26}$

Her account of her own reading of the book shares many of the characteristics of mysticism, while it rejects just such supernatural-tainted labels as inadequate to what she now conceives of as the natural experience behind it: 
I speak out of my own experience when I say that no myth, no "miracle" embodying the notion of a direct communication between God \& a human creature, goes beyond the effect, soul \& body, of those Poems on me: \& that were I to put into Oriental forms of speech what I experienced it would read like one of those old "miracles" or myths. Thus of many things that used to appear to me incomprehensible lies, I now perceive the germ of truth $\&$ understand that what was called the supernatural was merely an inadequate $\&$ too timid way of conceiving the natural. (Letters, 83)

The experience that has given her insight into the "myths and miracles"the stories of mysticism that modeled divine communication-was precisely the experience of reading Leaves: the interpenetration of book, soul, and body.

Gilchrist was certain that Whitman's views were an advance on current religious stances. Like many of Whitman's early readers (particularly those writing in the period after the American Civil and before the First World War), she focuses on his evolutionary, dynamic outlook and his enlightened treatment of the problem of evil:

What I, in my heart, believe of Whitman is, that he takes up the thread where Christ left it; that he inaugurates, in his own person, a new phase of religion; a religion which casts out utterly the abjectness of fear; sees the 'nimbus round every head,' knowing that evil, like its prototype darkness, is not a thing, an existence at all but the absence of a thingof light; of balanced and proportionate development-activities not having found their right outlet - or not yet subordinated by the higher ones that will by and by unfoldimpulses that have not yet opened their eyes to the beautiful daylight provided for them, but work in a kind of darkness as before birth, the soul remaining so much longer an embryo than the body - how often even when the hair is grey! So then is laid to rest the phantom of a Devil—of some 'power or being contending against God.' $(A G, 204)$

Like many proponents of a more liberal and universal religion-including Bucke, Huxley, Carpenter, and Wallace - she regards much of "what is called Christianity" as

not of Christ's making at all, but . . . the idea of Him, of His teaching, life and death passed to us through the darkening medium of infinitely less developed, less great and beautiful natures than His own-minds which clung with passionate tenacity to the traditions of their past - to the notions of a vindictive angry God to be propitiated by sacrifices and atonements; which seem to belong as inevitably to the early life of races as the belief in and dread of something cruel and terrible, ghost or demon lurking in the dark, does to childhood. $(A G, 205)$

The acceptance (which she saw as inevitable, despite Rossetti's cautionary comments) of Whitman's new vision would not only replace "Christianity," but would restore Christ's true message, by removing the superstructure of "system" which for Gilchrist is external and alien to it. Whitman's poetry would demolish, then, 
the childish and outgrown absurdities, the moral baseness in the idea of God interwoven (shaped on the pattern of an Eastern despot) with the memories of Christ's beautiful life and teaching and death into a system. ... [A]nd that demolition will happen now gently and quickly - now that there is once more a kindred human soul to Christ's on the earth - one filled with the same radiant glowing consciousness (it is a consciousness, not a belief) of the divine and immortal nature of the human soul-the same fearless, trusting, loving attitude towards God, as of a son, the same actual close embracing shape in what new and rich developments through the lips of this Poet! ... Now Christianity will go-and Christ be better understood and loved than $\mathrm{He}$ has been since those early times when His great personal influence yet vibrated in the world, and the darkness of His expounders had not begun to work adversely to the growing lights of succeeding times. $(A G, 205-206)$

Religion, rightly conceived, then, is not for Gilchrist a matter of belief, but of consciousness: Whitman and Christ both see the immortality of the soul, and effuse it by their "great personal influence." And for Gilchrist, it is this influence, this power to effect personal change that Leaves of Grass contains and effuses. She speaks of it in terms of potential forces that are reminiscent of her earlier writings on science. Indeed, Gilchrist sees Whitman's book as the answer to the poetic acceptance of science whose need she had predicted years before:

whoever takes up Walt Whitman's book as a student of Poetry alone, will not rightly understand it: many and many a line and passage will appear to him common, insignificant as a drop of water-has like that drop of water latent within it, power enough to furnish forth a flash of lightning and a peal of thunder if only it be taken up where the right conditions for liberating that force are present. I think he will one day win as ardent adhesion from men of science and philosophers, as from lovers of art, and they need him most of all. $(A G, 206)$

Gilchrist's letters often mention the effect of something like the release of this latent force-physically stirring, consciousness-altering, but at the same time a barely containable, possibly dangerous test of physical constitution. In the letters to Rossetti that would become "A Woman's Estimate of Walt Whitman," she writes that she "had not dreamed that words could cease to be words, and become electric streams like these," and that "strong" as she was, she felt "sometimes as if I had not bodily strength to read many of these poems" (Letters, 3-4).

This might be easily dismissed as simple rhetorical overstatement, but I suggest that Anne Gilchrist is doing something which Whitman's poetry suggests, which mystics of a certain sort have often done, and what she seems to have had a peculiarly strong ability to do: she is reading the text with her body. ${ }^{27}$ In her view, it very nearly killed her.

Late in the year of 1870 , as she was waiting with increasing impatience for a direct response from Whitman about her freshly-published "Estimate," Anne Gilchrist was taken to bed with a strange illness. For months she languished, getting weaker and weaker, until it seemed to 
those around her that she would die. Biographers and critics have implied that the illness was nervous or psychosomatic, a crushing emotional effect of Whitman's seeming indifference to her critical-romantic overture. ${ }^{28}$ However, Gilchrist's own interpretation of the illness is given in terms of what she conceived of as the "miracle" of the effect of Leaves of Grass. "Had I died the following year" [after reading the book], she writes, "it would have been the simple truth to say I died of joy." The doctor's diagnosis had been "nervous exhaustion falling with tremendous violence on the heart which 'seemed to have been strained"' (Letters, 83). Gilchrist writes that she left the bewildered doctor "in his puzzle-but it was none to me. How could such a dazzling radiance of light flooding the soul, suddenly, kindling it to such intense life, but put a tremendous strain on the vital organs? how could the muscles of the heart suddenly grow adequate to such new work?" The "strain" on the heart was, as Gilchrist interpreted it for Whitman, the result of "yearnings . . . that I might repay with all my life \& soul \& body this debt-that I might give joy to him who filled me with such joy, that I might make his outward life sweeter \& more beautiful who made my inner life so divinely sweet and beautiful" (Letters, 83). If this is lovesickness, it is lovesickness of a very peculiar kind. This prostration was the consequence of something like the mystic's dark night of the soul (and body) that ended the first and most fervent blush of a spiritual enthusiasm. Afterward, in a letter to Whitman, she would look back upon this first passion with nostalgia and wistfulness:

$\mathrm{Ah}$, shall I ever attain to the Ideal that burst upon me with such splendour of light $\&$ joy in those poems of 1869-so filling, so possessing me, I seemed as if I had by one bound attained to that ideal - as if I were already a very twin of the soul from whom they emanated. But now I know that divine foretaste indicated what was possible for me, not what was accomplished-I know the slow growth - the standstill winters that follow the growing joyous springs \& ripening summers. I believe it will take more lives than this one to reach that mountain on which I was transfigured again, never to descend more, but to start thence for new heights, fresh glories. Ah, dear friend, will you be able to have patience with me, for me? (Letters, 125)

How the individual reader inserts himself or herself into a text, how the text contains or creates with the reader's collusion "roles" which the reader may choose to accept or resist, has become the object of critical attention only relatively recently. Wolfgang Iser called his version of the theory the "implied reader." Anne Gilchrist perceived just such a role in Whitman's works, particularly those like "the series headed 'Calamus,' for instance, ... . some of the 'Songs of Parting,' the 'Voice out of the Sea,' the poem beginning, 'Tears, Tears,' \& c.," in which, she said "there is such a weight of emotion, such a tension of the heart, that . . . I am obliged to lay the book down for a while" (Letters, 4). Marion Alcaro 
writes that Anne initiates a myth of Whitman as "the solitary singer searching for the perfect mate" but also rightly notes that "no one so mythologized Whitman as Whitman himself."29

\section{Contacting Whitman}

In her first letter directly to Whitman, Gilchrist announces: "In May, 1869, came the voice over the Atlantic to me- $\mathrm{O}$, the voice of my Mate" (Letters, 60-61). This bold statement both complexly echoes the situation and wording of "The Word Out of the Sea" and accepts without cavil or reservation the role which she had felt "called" to by Whitman's poems. ${ }^{30}$ In "The Word Out of the Sea," the poem that would later be retitled "Out of the Cradle Endlessly Rocking," the poet's persona recalls a childhood encounter in May, when "the Fifth-month grass was growing," when he heard the voice of a mocking-bird calling in vain across the sea to his lost mate. Gilchrist's reference here is remarkable: it shows that she has imagined the poem not as a only as a meditation on the boy's reaction to the call of the forlorn mocking-bird. Instead, the function of the poem echoed, for Gilchrist, the mocking bird's call for the lost mate. Anne identified not with the boy, or with the singing bird, but with the lost mate. When the lovelorn mockingbird sang "With this just-sustain'd note I announce myself to you; / This gentle call is for you my love, for you," Anne Gilchrist heard the voice of Whitman calling to her across the sea, and responded (LG 1867, 203).

The surprising directness of Whitman's poems, with their confidential whispers, their challenges and seductions of the reader, their urgings to union with text, poet, and soul, had done their work on Anne Gilchrist with her own participation. Her response was as complete and as deep as any of Whitman's contemporary readers.

The role which Anne Gilchrist read from the poems, modified in the course of her reading, and then assumed was a complex one. In Whitman's poetry, perhaps most notably in the poems of the Calamus sequence, the language of reading, of religious discipleship, of intimate friendship, of romantic or sexual attraction, and of the union of souls is almost inextricably entangled. One implies the rest, and the whole complex is susceptible to being read in terms of any one of them. Unlike Richard Maurice Bucke's interpretation, which almost unfailingly converts the sexual into metaphoric accounts of cosmic consciousness, the reading implied in Gilchrist's criticism and letters, the understanding that Whitman called "better and fuller and clearer" than others, is a response to each of these levels of meaning. Very few of Gilchrist's most shocking overtures or responses cannot be traced to particular poems in Leaves of Grass. 
Whitman's poetry, particularly the Calamus sequence, asks for and constructs its own ideal readers-who will feel the poems in their bodies, who will follow Whitman as both lover, companion, and spiritual mentor, who will reciprocate Whitman's feelings, and who will eventually draw themselves level with him and partake of his thoughts and feelings as if they were their own. Gilchrist confides to Whitman that as she read his book she felt "all folded round in thy love," that she felt "as if thou wast pleading so passionately for the love of the woman that can understand thee," and that she did not know "how to bear the yearning answering tenderness that fills my breast" (Letters, 66). She is responding to a reader-directed structure in Whitman's poems which expresses a longing for a communion of understanding and emotional involvement with the reader.

In the Calamus poem, "Among the Multitude," Whitman sets up such a relationship. The poem, like so many, addresses a reader who considers him- or herself as a prospective "eleve," student, or lover of Whitman and his book. ${ }^{31}$ It depends on and reinforces something like the pride of interpretation and a sense of sympathy and creates, in the reader who accepts the role it offers, a sense of being chosen by the poet. The subject and addressee of the poem is a "lover and perfect equal" whom Whitman's speaker, playing the voyeur of the reading process, perceives "picking me out by secret and divine signs, / Acknowledging none else - not parent, wife, husband, brother, child, any nearer than I am" ( $L G 1867,143$ ). The poem sets up the seeker as "knowing" Whitman through all his indirections, while other readers are "baffled," unable to pick their way through the signs that reveal as well as obfuscate him. Gilchrist here must have felt a privileged interpreter, knowing as she did from the Rossetti preface the poor critical estimate that Whitman had received in the years before. ${ }^{32}$ When Whitman states in the last stanza that "I meant that you should discover me by so faint indirections, / And I when I meet you, mean to discover you by the like in you," he reaffirms his intention and sets up the expectation of reciprocity of feeling and an opening between a courtship by book and by look that Gilchrist eagerly seizes ( $L G 1865,143)$. She clearly considered herself a perfect reader of Leaves and said as much, writing that

with the blue sky opening to me $\&$ a soft breeze blowing in $\&$ the Book that is so dearmy life-giving treasure- open on my lap, I have very happy times. No one hundreds of years hence will find deeper joy in these poems than I-breathe the fresh, sweet, exhilarating air of them, bathe in it, drink in what nourishes \& delights the whole being, body, intellect, \& soul, more than I. Nor could you, when writing them, have desired to come nearer to a human being $\&$ be more to them forever $\&$ forever than you are $\&$ will be to me. (Letters, 112) 
The courtship of the reader in Whitman has another element, however, which seems to agree with Gilchrist's conception of spiritual love, the rhetoric of which pervades her letters to Whitman. It is the idea of the lover or comrade as a fragment of the self or the soul, and the corollary conception of the book as the medium of interaction or a stand-in for the soul of the lover. In her first letter to Whitman, Gilchrist writes that

a woman is so made that she cannot give the tender passionate devotion of her whole nature save to the great conquering soul, stronger in its powers, though not in its aspirations, than her own, that can lead her forever \& forever up and on. It is for her soul exactly as it is for her body. The strong divine soul of the man embracing hers with passionate love-so alone the precious germs within her soul can be quickened into life. And the time will come when man will understand that a woman's soul is as dear and needful to his and as different from his as her body to his body. That was what happened to me when I had read for a few days, nay, hours, in your books. It was the divine soul embracing mine. I never before dreamed what love meant: not what life meant. Never was alive before-no words but those of "new birth" can hint the meaning of what then happened to me. (Letters, 59)

Gilchrist's first metaphor for reading here is literally one of enlightenment - of light coming forth from the soul of the poet and brightening the soul of the reader. It is repeated throughout her letters. The other metaphor for reading or influence will also underlie much of what she writes to Whitman - the image of the intercourse of the souls of author and reader, fertilizing the soul into a "new birth." This congress of souls may have underlying it a reading of Section 5 of "Song of Myself."

Gilchrist seems to understand Whitman's procreative and germinal imagery (in poems like the Children of Adam sequence) in a spiritual or imaginative sense here-the embrace of the poet brings the seeds inside to life. The magnetic soul of the poet attracts the student/lover soul, and brings it closer and closer to being fit for union. Gilchrist writes to Whitman that if she were to die, she would want him to be able to say:

"This woman has grown to be a very part of me. My soul must have her loving companionship everywhere $\&$ in all things. I alone $\&$ she alone are not complete identities - it is I and she together in a new divine, perfect union that form the one complete identity." (Letters, 66)

But the possibility that there is a carnal union or a more tangible conception desired is in the background-expressed in her hint in the same letter that "I am yet young enough to bear thee children ... . if God should so bless me." The begetting of "perfect children" in the Children of Adam sequence may be a literary metaphor for influence and spiritual fertilization, or may be a literal desire. Gilchrist takes account of both 
meanings and attempts to show her acceptance of the one and her willingness for the other.

It is one of the Calamus lyrics, however, which Gilchrist relates most to her own process of courting Whitman. She writes that "in moods of pain and discouragement, dear Friend, I turn to the Poem beginning, 'Whoever you are holding me now in hand,' and I don't know but that that one revives and strengthens me more than any. For there is not a line nor a word in it at which my spirit does not ride up instinctively and fearlessly say-'So be it'" (Letters, 89).

A close examination of the poem shows the elements of Gilchrist's relationship with Whitman. In "Whoever you are, Holding me now in Hand," Whitman melds the language of discipleship, reading, and furtive sexual intimacy. It is one of a number of poems that act to encourage or discourage Whitman's devoted reader/lover/disciple/student, or to shift the "eleve's" perceptions of what her or his task is about. The title of the poem evokes both the image of Whitman and the reader holding hands in intimacy and the reader holding the physical book which here stands in for and represents itself as Whitman.

In Whitman, the image of handholding represents the poet's intimate friendship with the reader as well as his intention to lead in a spirit of mutual affection, to outstretch a hand of friendship and aid. Not only in "Whoever you are, Holding me now in Hand" but also in "To You," Whitman urges the reader to come with him: "Let us twain walk aside from the rest," he writes ( $L G 1867,258)$. He urges the reader to "Tell me what you would not tell your brother, wife, husband, or physician." In "Of the Terrible Doubt of Appearances," the image takes on an almost mystical weight; the beloved's hand in the speaker's hand imparts "the sense that words and reason hold not" and charges him with "untold and untellable wisdom" ( $L G 1867,127)$. The motif is common to many of the other reader-focused and companion-focused lyrics. Gilchrist neatly appropriates this image and uses it in her letters, writing that she often delights "to touch, to press to me the beloved books-like a child holding some hand in the dark-it knows not whose-but it knows it is enough - knows it is a dear, strong, comforting hand" (Letters, 65). When she reads Whitman's poems, she tells him, she is "not groping then, but hand in hand with you, breathing the air you breathe, with eyes ardently fixed in the same direction as your eyes look, heart beating strong with the same hopes, aspirations, yours beats with" (Letters, 115). Her acceptance and willingness to be led is shown in another use, where she writes to Whitman that she takes "the hand you stretch out each dayI put mine into it with a sense of utter fulfillment: ask nothing more of time and of eternity but to live and grow to that companionship that includes all" (Letters, 112). 
"Whoever you are" is a flirtation, a cryptic hint, a playful discouragement, an incitement to union both mystical and carnal, and an exploration of the act of reading. "Without one thing," Whitman states, opening the first of several secrets into which the reader must enter, "All will be useless ... I am not what you supposed, but far different" ( $L G 1867,122)$. One of the great difficulties in trying to pin Whitman to one meaning here is to imagine what he is expecting from his reader's initial presuppositions: is the book not a book, or is the voice of Whitman not really a separate man? Is Whitman saying that he is not the persona he has created? As we shall see later, Gilchrist is quick to identify Whitman with his book and wary of accepting that the Whitman she finds in the book is illusion. Whitman here unsettles meaning, creates a place for the reader to work, stirs up questions, makes distinctions ambiguous, creates a place of mystery. We cannot know, when Gilchrist said "So be it," what precisely she was "assuming."

Whitman's poetry hints at an ideal reader, and creates a role for the real reader to accept, modify, or reject. Like "Among the Multitude," "Whoever you are" asks the reader to include himself or herself in a sort of elite cadre of readers. When Whitman asks, "Who would sign himself a candidate for my affections," the reader here is clearly intended to include himself or herself in the list-Gilchrist certainly did ( $L G 1867$, 122). To read the poem is to be given an offer, to be challenged to vie for a privileged place, to contract oneself as an aspirant.

The gender of the person addressed is ambiguous in the poem, though not so carefully left open as some others. Whitman frequently takes care to speak to both men and women and alternate his pronouns. Here, however, he speaks of the reader signing "himself." The implication that the intended reader is male is of course undercut or complicated by Whitman's assertion that he is "the new husband" - who would receive "the new husband's kiss" ( $L G 1867,123)$. Gilchrist, despite her critical acuity, never seems to have seen a homosexual subtext in Calamus (though of course very few did at the time). Instead, the sequence, like the Children of Adam poems, is a spiritual, physical, and emotional courtship open to her as a woman. ${ }^{33}$

Whitman implies that to meet the demands of the text the reader must also be a non-conformist, unheeding of the opinion of society, eager for adventure and willing to change, must "give up all else" and abandon "the whole past theory of your life and all conformity to the lives around you," 34 though the result may be "uncertain, perhaps destructive." In Gilchrist's letters, she displays always a fearless desire to prove her devotion to Whitman, to qualify herself in this sense. In that first letter to Whitman, she writes "I can wait - any time, a lifetime, many lifetimes-I can suffer, I can dare, I can learn, grow, toil" (Letters, 
61). She even expresses her willingness to die with Whitman, if it were called for, writing, "If God were to say to me, 'See- he that you love you shall not be given to in this life-he is going to set sail on the unknown sea-will you go with him?' never yet has bride sprung into her husband's arms with the joy with which I would take thy hand \& spring from the shore." Clearly she was not daunted by Whitman's warning that his eleve's "novitiate would even then be long and exhausting" ( $L G$ $1867,122)$.

The reader, proceeding through the poem, is offered a sort of test of devotion. "Therefore release me now before troubling yourself any further, let go your hand from my shoulders," says Whitman, speaking as the book itself, "Put me down and depart on your way" ( $L G 1867$, 122). Now that the cowardly and conforming have, we are to imagine, stopped reading, Whitman continues, more intimate with his confirmed novice, suggesting a tryst that reminds one again of Whitman's demand that his audience read alone, and out of doors. ${ }^{35}$ Gilchrist follows this injunction, writing to Whitman a number of times describing the situation of her reading-sometimes enlivening her domestic chores with Whitman's verse, but most often reading outdoors, as when she writes that she sat "in a beautiful garden (the old Priory garden) with my beloved Poems and the dew-laden flowers and liquid light and sweet, fresh air; $\&$ the sparkle of the pond \& delicious greenness of the meadows beyond \& rustling trees, and had a joyful time with you, my Darling" (Letters, 115).

Isolated in nature, alone, having abandoned the formal setting, the "roof'd room" or "company," with all the nervous secrecy of lovers, ${ }^{36}$ the book/body/soul of Whitman and the reader may know one another:

Here to put your lips upon mine I permit you,

With the comrade's long-dwelling kiss or the new husband's kiss,

For I am the new husband and I am the comrade. ( $L G 1867,123)$

This tryst and exchange of affections recalls and is echoed by (or prefigures an understanding of) Section 5 of "Song of Myself," which takes on further implications when read together with this and other moments of reader-address and sensual abandon in Leaves.

The kiss upon the lips may be construed as an image of reading aloud: Whitman, in the act of reading, has penetrated the reader, and forced his or her lips - the embodied word moves through them like air. Gilchrist writes that when she reads Whitman's poems, she is "breathing the air" that he breathes (Letters, 115).

The affection the reader is expected to yield is clearly returned, as the book desires to be carried "Where I may feel the throbs of your heart or . . rest upon your hip" ( $L G 1867,123)$. Whitman, who has 
already made claims to be watching from afar, now feels a magnetic attraction to the body of his reader.

But while it may be safe to carry the book, it is not necessarily safe to attempt to understand it. "These leaves conning," Whitman writes, the reader "cons at peril." Whitman again dissuades, taunts, reveals concealment:

For these leaves and me you will not understand,

They will certainly elude you at first and still more afterward, I will certainly elude you,

Even while you should think you had unquestionably caught me, behold! Already you see I have escaped from you. ( $L G 1867,123)$

In this extraordinary passage, Whitman plays a disappearing-trick with the act of reading. "Behold!" Whitman, who seemed so close, as close as the voice in one's head, the words on the lips, is now gone in the pause between lines. The embodied word, the inspiring breath moves out of the mouth and disappears into the empty air. The text remains. The voice has escaped.

"For it is not what I have put into it that I have written this book," Whitman writes - which is certainly true at one level: it is for the reform of the reader, for the possibility of rapport, for the creation of future generations of personalities. "Nor is it by reading it you will acquire it," as he says: it is by pursuing your own flight in the same air, by having corresponding thoughts, by making inquiries, by watching yourself, perhaps. Whitman once again acknowledges the danger of change, and the unproved nature of the endeavor the reader is contemplating, the task he or she signs up for by reading Whitman: "For all is useless without that which you may guess at many times and not hit, that which I hinted at; / Therefore release me and depart on your way": Whitman again teases with a classic rhetorical gesture of those who would keep people looking for a secret: he denies their ability to find it. This is a classic use of what I will call Whitman's rhetoric of the open secret. By merely suggesting a secret, he keeps the reader reading, and drives him or her back to read or re-read the other poems. Perhaps, as in a Zen koan, the answer is not so important as is the effort, and the arousal of the sense of significance. In the presence of a mystery, everything stands as a possible clue.

Another of the Calamus poems seems to raise themes central to the issue of Anne's reading, though, perhaps unsurprisingly, it is one she never mentions. In "Are you the New Person Drawn Toward me?" Whitman apparently seeks to check or modify the conceptions of those of his readers who would take his persona either too lightly or too literally. "To begin with take warning," Whitman admonishes his enthusi- 
astic reader; "I am surely far different from what you suppose" ( $L G$ $1867,129)$. Though this again begs the question of preliminary suppositions, the questions Whitman asks afterwards clarify what he expects here:

Do you suppose you will find in me your ideal?

Do you think it so easy to have me become your lover?

Do you think the friendship of me would be unalloy'd satisfaction?

Do you think I am trusty and faithful?

Do you see no further than this façade - this smooth and tolerant manner of me?

Do you suppose yourself advancing on real ground towards a real heroic man?

Have you no thought, $\mathrm{O}$ dreamer, that it may be all maya, illusion? ( $L G 1867$, 129-30).

Nonetheless, the complete identification which Gilchrist made between the book Leaves of Grass and its author is suggested and encouraged in a number of Whitman's poems, perhaps most notably in "So Long," which assumed the important final position in both Rossetti's selection and the 1867 edition of Leaves. In that poem, Whitman announces,

My songs cease-I abandon them,

From behind the screen where I hid, I advance personally, solely to you.

Camerado! This is no book,

Who touches this touches a man,

(Is it night? Are we here alone?)

It is I you hold, and who holds you,

I spring from the pages into your arms - decease calls me forth. ( $L G 1867,35 \mathrm{c})$

After the first of Gilchrist's letters, Whitman apologized for not writing a longer reply and confirmed her reading by pointing her back to his book, which was, he said "my best letter, my response, my truest explanation of all. In it I have put my body and spirit" (Letters, 67). However, by March of 1872, Whitman felt the need to caution Gilchrist:

Dear friend, let me warn you somewhat about myself- \& yourself also. You must not construct such an unauthorized \& imaginary ideal Figure, \& call it W. W. and so devotedly invest your loving nature in it. The actual W. W. is a very plain personage, \& entirely unworthy such devotion. ${ }^{37}$

Gilchrist's response to this warning is defensive, and grounded in her understanding of Whitman's poems:

If it seems to you there must needs be something unreal, illusive, in a love that has grown up entirely without the basis of personal intercourse, dear Friend, then you do not yourself realize your own power nor understand the full meaning of your own words, "whoso touches this, touches a man"- "I have put my Soul \& Body into these poems." 
Real effects imply real causes. Do you suppose that an ideal figure conjured up by her own fancy could, in a perfectly sound, healthy woman of my age, so happy in her children, so busy \& content, practical, earnest, produce such real $\&$ tremendous effectsaturating her whole life, colouring every waking moment-filling her with such joys, such pains that the strain of them has been well nigh too much even for a strong frame, coming as it does, after twenty years of hard work? ${ }^{38}$

Gilchrist, however, did tone down some of the excesses of the first letters, and Whitman did not "warn" her in the same way again. The relationship continued, with occasional ardors and occasional distancings on one side or another, until finally Anne and Walt met.

\section{Meeting and After}

Emerson's essay, "Friendship," with which both Gilchrist and Whitman must have been familiar, has some interesting things to say about friendships like the one between them. In the beginning of the essay, Emerson notes the thrill of the soul that happens when first meeting a stranger who

stands to us for humanity. He is what we wish. Having imagined and invested him, we ask how we should stand related in conversation and action with such a man, and are uneasy with fear. The same idea exalts conversation with him. We talk better than we are wont. We have the nimblest fancy, a richer memory, and our dumb devil has taken leave for the time. For long hours we can continue a series of sincere, graceful, rich communications, drawn from the oldest, secretest experience. . . . ${ }^{39}$

Emerson goes on to mourn the inevitable loss of this first thrill and frisson, this loss of the stranger, the universal gap that brings out our own best. But later in the essay, Emerson comes to the idea that

Friendship, like the immortality of the soul, is too good to be believed. The lover, beholding his maiden, half knows that she is not verily that which he worships; and in the golden hour of friendship, we are surprised with shades of suspicion and unbelief. We doubt that we bestow on our hero the virtues in which he shines, and afterwards worship the form to which we have ascribed this divine inhabitation. In strictness, the soul does not respect men as it respects itself. (Emerson, "Friendship," 343-344)

But Whitman's book, in providing an ideal personality and model intended for ages and audiences to come, also provided, for Anne Gilchrist, a friend and lover who could - and was made to-be invested with her own sympathizing nature. Whitman as reflected in the book is both an intimate and a permanent stranger: the Walt Whitman whom Gilchrist would meet, no matter how charming, friendly, sympathetic, greatsouled, could play this role only imperfectly-especially as the role Gilchrist responded to was by that time quite different from the "Good 
Gray Poet" role he was currently engaged in. On one level at least, the Whitman that Gilchrist fell in love with was a reflection of herself. Emerson writes of the new friend that "Our own thought sounds new and larger from his mouth" (Emerson, "Friendship," 343). This parallels what he writes of books of genius; in them "we recognize our own rejected thoughts: they come back to us with a certain alienated majesty." 40

Gilchrist's last work on Whitman is justly called "A Confession of Faith"-it was written after she had met Whitman, lived in close proximity to him for a number of years, and then gone back to live in England. She had since continued her literary labors, writing a short but important and sympathetic biography of Mary Lamb, the brilliant sister of the Romantic poet Charles. Anne's life had since been touched by a tragedy - the death of her daughter Beatrice (Walt's favorite) by suicide. ${ }^{41}$ She was much troubled by emphysema, and in 1881 she had found that she had incurable cancer of the breast. "A Confession of Faith" is consciously her final word on Whitman.

It is less a work of enthusiasm than her "A Woman's Estimate of Walt Whitman," written some fifteen years earlier. Unlike the earlier work with its attempts to defend Whitman's style and material against then-current critical attacks, Gilchrist's last essay on Whitman focuses on explaining how Leaves should be approached. The purpose of the essay is to "indicate the scope and source of power in Walt Whitman's writings, starting from no wider ground than their effect upon an individual mind," and to "suggest such trains of thought, such experience of life as having served to put me en rapport with this poet may haply find here and there a reader who is thereby helped to the same end" (Letters, 25). It begins with a long quotation from William Wordsworth:

"Of Genius in the Fine Arts," wrote Wordsworth, "The only infallible sign is the widening [of] the sphere of human sensibility for the delight, honour, and benefit of human nature. Genius is the introduction of a new element into the intellectual universe, or, if that be not allowed, it is the application of powers to objects on which they had not before been exercised, or the employment of them in such a manner as to produce effects hitherto unknown. What is all this but an advance or conquest made by the soul of the poet? Is it to be supposed that the reader can make progress of this kind like an Indian prince or general stretched on his palanquin and borne by slaves? No; he is invigorated and inspirited by his leader in order that he may exert himself, for he cannot proceed in quiescence, he cannot be carried like dead weight. Therefore to create taste is to call forth and bestow power." (Letters, 23)

"A great poet, then," writes Gilchrist, "is a "challenge and a summons."” The question is not "whether we like or dislike him, but whether we are capable of meeting that challenge, of stepping out of our habitual selves to answer that summons." A poet "makes greater demands upon his 
reader than any other man. For it is not a question of swallowing his ideas or admiring his handiwork merely, but of seeing, feeling, enjoying, as he sees, feels, enjoys" (Letters, 23-24). Explaining Whitman's attempt to "give scope and elevation and beauty to the changed and changing events, aspirations, conditions of modern life," she calls on the reader to recognize that with "new aims [come] new methods." In order to let Whitman's poems work properly, she enjoins the reader not to "approach these poems as a judge, comparing, testing, measuring by what has gone before, but as a willing learner, an unprejudiced seeker for whatever may delight and nourish and exalt the soul" (Letters, 25). She is obviously speaking from her own method, her own attitudes, her own experience of the poems. As she quotes:

"The messages of great poems to each man and woman are," says Walt Whitman, "come to us on equal terms, only then can you understand us. We are no better than you; what we enclose you enclose, what we enjoy you may enjoy"- no better than you potentially, that is; but if you would understand us the potential must become the actual, the dormant sympathies must awaken and broaden, the dulled perceptions clear themselves and let in undreamed of delights, the wonder-working imagination must respond, the ear attune itself, the languid soul inhale large draughts of love and hope and courage, those "empyreal airs" that vitalize the poet's world. (Letters, 24-25)

Gilchrist did her best to respond to the call of these poems, and it is clear that, regardless of her changing relationship with Whitman the person, she remained certain of the beneficial effects of Leaves.

Those writers who have commented on the relationship between Gilchrist and Whitman have frequently focused on the one-sidedness of their correspondence. Anne Gilchrist, though, wrote that she had envied the first husband who had loved her with a fervor she could not requite. She believed it more beneficial to be the lover than the beloved. No matter how one-sided, loving relations in the right spirit, with the right people, led to spiritual progress. Emerson would not have disagreed. In "Friendship," he wrote of just such apparently one-sided correspondences:

It is thought a disgrace to love unrequited. But the great will see that true love cannot be unrequited. True love transcends the unworthy object, and dwells and broods on the eternal, and when the poor interposed mask crumbles, it is not sad, but feels rid of so much earth, and feels its independency the surer. Yet these things may hardly be said without a sort of treachery to the relation. The essence of friendship is entireness, a total magnanimity and trust. It must not surmise or provide for infirmity. It treats its object as a god, that it may deify both. (Emerson, "Friendship," 354)

If the most passionate love was not returned in kind, still something very important was. Whitman and Gilchrist became close friends. Whitman the man stayed under Gilchrist's roof, befriended her chil- 
dren, talked with her endlessly, and came to greatly admire her. After her death, he often spoke of her emotionally to the other disciples. He composed for her the "memory-leaf" "Going Somewhere," eulogizing her as his "science friend," his "noblest woman-friend . . . Now buried in an English grave." "2 "Going Somewhere"” seems a typically Whitmanian poem in many ways, and it is easy to find it unremarkable until one notices that the burden of the poem, the assertion of endless progress, endless growth, endless travel towards some unknown but sure and fitting end, is presented as a quotation from Gilchrist's conversation. When Whitman has spoken with other voices, he has assumed them. In Gilchrist's case, he gives her the unprecedented honor of presenting his poem as her quoted words. It is a fitting tribute, I think, for the woman who had used Whitman's poems to find her own voice again.

\section{Texas AEM University}

\section{NOTES}

1 I refer readers to the well-balanced treatment in Jerome Loving's Walt Whitman: The Song of Himself (Berkeley: University of California Press, 1999), to Marion Walker Alcaro's admirably complete biography of Gilchrist, Walt Whitman's Mrs. G(London: Associated University Presses, 1991), and to Thomas B. Harned's edition of The Letters of Anne Gilchrist and Walt Whitman (Garden City, New York: Doubleday, Page \& Company, 1918). Elizabeth Porter Gould's Anne Gilchrist and Walt Whitman (Philadelphia: David McKay, 1900) and Herbert Gilchrist's uneven and patchwork Anne Gilchrist: Her Life and Writings (London: T. Fisher Unwin, 1887) are both valuable sources, but, written without access to the letters in the Harned edition (which Whitman had refused Herbert Gilchrist as "too sacred"), they show only a portion of the relationship.

2 Anne Gilchrist: Her Life and Writings, ed. Herbert Harlakenden Gilchrist, 142. Hereafter cited parenthetically as $A G$.

3 Early critics had a variety of theories to account for the failure of a conventional romantic relationship to develop between the two. Thomas Harned, in his preface to The Letters of Anne Gilchrist and Walt Whitman, follows Emory Holloway in claiming that the problem was that Whitman's heart was "so far as attachments of that sort were concerned, already bestowed elsewhere," namely to a "certain woman" to whom Whitman had written "Out of the Rolling Ocean the Crowd" (xxxii).

4 Walt Whitman, The Correspondence, ed. Edwin Haviland Miller (New York: New York University Press, 1961), 2:2.

5 Louisa Van Velsor Whitman recognized Gilchrist's critical acuity. She read Anne's "A Woman's Estimate of Walt Whitman," and wrote to him "i got the 2 radicals [The Radical - the magazine in which Gilchrist's essay was published] and the other the next i set right down and read it that Lady seems to understand your writing better than ever anyone did before as if she could see right through you she must be a highly educated woman." See Sherry Ceniza, Walt Whitman and Nineteenth-Century Women Reformers (Tuscaloosa: University of Alabama Press, 1998), 25. 
6 Paul J. Ferlazzo, "Anne Gilchrist, Critic of Walt Whitman," South Dakota Review 10 (Winter 1972), 64.

7 Suzanne Ashworth, "Lover, Mother, Reader: The Epistolary Courtship of Walt Whitman," Nineteenth-Century Contexts 26 (June 2004), 173-197. Ashworth treats Gilchrist's rhetoric in some depth, focusing on her active role in "seducing" Whitman. The present article does not answer Ashworth's provocative analysis directly, as it came to my attention after this article was accepted for publication. Suffice it to say that Ashworth does a fine job capturing the multifaceted persona that Gilchrist projects in her letters.

8 "A Woman's Estimate of Walt Whitman," an edited selection of Gilchrist's early letters concerning Whitman to William Michael Rossetti, was published in the Boston Unitarian magazine, The Radical, in May 1870. It was later republished under the name "An Englishwoman's Estimate of Walt Whitman" in Herbert Gilchrist's collection of his mother's writings, Anne Gilchrist: Her Life and Writings.

9 Thomas B. Harned, ed., The Letters of Anne Gilchrist and Walt Whitman, 77. Hereafter cited parenthetically as Letters.

10 Walt Whitman, Leaves of Grass (New York: Wm. E. Chapin \& Co., 1867). Hereafter cited parenthetically. An electronic facsimile and transcription of the 1867 edition is available online from The Walt Whitman Archive, ed. Ed Folsom and Ken Price, www.whitmanarchive.org.

11 Emerson's reputation was at an ebb in England at the time, largely the result of his English lectures of 1840s, which criticized British social problems.

12 Whitman would call her his "science-friend" in the poem written to her memory, "'Going Somewhere."”

13 Anne Gilchrist, "The Indestructibility of Force," Macmillan's Magazine 6 (August 1862), 337.

14 "If the call comes" has a double meaning here-while she anticipates a future expanded role for women, she is also awaiting a more personal call to action: a response from Whitman.

15 In the preface to Herbert Gilchrist's memoir of Anne, William Michael Rossetti sums up Anne's character thus: "hers was a life of earnest, warm, and unfrittered simplicity, holding an even and sensitive balance between the claims of family-affection and those of intellectual activity. To make the home a centre of mental as well as family vital energy may perhaps have been her ideal; it was, at any rate-so far as I may be permitted to form an opinion-her lifelong practice" ( $A G, \mathrm{xv}-\mathrm{xvi})$.

16 Anne Gilchrist, “A Neglected Art,” Macmillan's Magazine 12 (October 1865), 501.

17 Herbert Spencer, Social Statics (New York: Robert Schalkenbach Foundation, 1954), 68.

18 Carlyle's 1851 The Life of Fohn Sterling is an attempt by Carlyle to rescue the reputation of his friend from theological criticism Sterling had received after his death. Carlyle, as Sterling's literary executor, portrays him as a noble, lovable, sympathetic, and tragic figure. If Carlyle can be said to be "tender" in any work, it is this one. 
19 Gilchrist met Scudder, the editor of the Riverside Literature Series and, at a later point, The Atlantic Monthly, along with Thomas Wentworth Higginson, Charles Eliot Norton, and a number of other Boston literati, on the strength of Rossetti's letters of introduction. See Alcaro, 195, and Gould, 45.

20 Horace E. Scudder, "Anne Gilchrist," in Men and Letters: Essays in Characterization and Criticism (Freeport, NY: Books for Libraries Press, 1972), 194. Scudder's essay is largely an appreciation of her personality. It has moments of considerable insight, noting for instance how Anne "uses [Whitman] as a whole to carry forward her thought, to enlarge her conceptions of human life, and to solidify and define floating notions of science and religion which had long been forming in her mind" (111).

21 Ferlazzo, "Anne Gilchrist, Critic of Walt Whitman," 64.

22 See Loving, 220.

23 Rossetti, ever-tactful, answered Gilchrist's letter with a delicate touch, saying "I very much like \& sympathize with (broadly considered) what you say of Whitman \& Christ; it is really the gist of the matter, \& ought by rights have been included in what was printed," but also defending Homer and Shakespeare, along with a less-restricted view of what makes a poet. William Michael Rossetti, Letters of William Michael Rossetti to Anne Gilchrist and Herbert Gilchrist, ed. Clarence Gohdes and Paull Franklin Baum (Durham: Duke University Press, 1934), 61.

24 Edward Carpenter, Days with Walt Whitman: With Some Notes on His Life and Work, and Three Portraits (London: George Allen, 1906), 16-17.

25 Ted Genoways's presentation, “The Picture of a Perfect Loafer': The Frontispiece to the 1855 Edition of Leaves of Grass," at the Leaves of Grass $150^{\text {th }}$ Anniversary Conference at Lincoln, Nebraska, tells of the interesting history of this image. This paper will be expanded into an essay for Leaves of Grass: The 150 th Anniversary, ed. Kenneth M. Price, Susan Belasco, and Ed Folsom (Lincoln: University of Nebraska Press, forthcoming). The re-engraved image seems to have a slightly curlier beard than the "original" of the 1855.

26 She also gives as a possible source of this power Whitman's suffering in the Civil War hospitals, and the sacrifice of his health for his message.

27 Paul Ferlazzo writes of this bodily knowing that "Whitman's sensual response to life has been transmitted through his poetry to Mrs. Gilchrist. That is, she acceptsseriously-the command that these poems enter your bloodstream and give your self awareness of your body's life. Such a process is absurd and unfathomable unless it be mystical." (Ferlazzo, 75-76).

28 Jerome Loving notes that the symptoms sound like "'neurasthenia,' a nervous disorder Victorian-era women frequently experienced" and this is certainly the case (Loving, 330). This underlines the importance of attribution of causes to the way we understand (or "have") our experience. We could find a common cause: "love-sickness" for Gilchrist's reaction, or a Freudian one (repressed sexuality), or very possibly a medical one. Had Gilchrist believed this diagnosis, the effect would have been different: instead, she attributed her feelings to a more spiritual source, and made them less a medical or mental problem than a stage in her sudden and violent emotional and spiritual evolution.

29 Alcaro, 121. In fact, almost all of Whitman's disciples took part in the mythmaking and perpetuating process that constructed Whitman's public image. W. D. 
O'Connor's The Good Gray Poet and "The Carpenter," along with the works of Bucke and Burroughs provide many examples.

30 Loving (329-330) links Anne's use of this language to "Out of the Rolling Ocean the Crowd," which fits Anne's situation quite well, but seems less a "call" and does not use either the date or the "mate" in the way that Anne uses in her letters. In any event, Gilchrist's role comes certainly not from a single poem, but from a complex synthesis of many.

31 This is Whitman's term, which in French simply means "student" but which takes on a complex coloration of apprentice, initiate, would-be lover, and spiritual seeker throughout his use of it.

32 And indeed, Whitman and the American disciples were very glad indeed to have Gilchrist's "Estimate." As the opinion of a British woman-respectable, well-educated, a mother-Gilchrist's writings undercut many of the more scurrilous accusations made about the unsuitability of Whitman's poetry for decent women.

33 Edward Carpenter's whole social ethic, on the other hand, as well as his utopian idealism will turn on a reading of Calamus as passing a mystical experience on to a sort of homosexual cosmic brotherhood.

34 Michael Sowder, in "Walt Whitman the Apostle" (Walt Whitman Quarterly Review 16 [Winter/Spring 1999]), treats "Whoever You Are" and Leaves in general as examples of conversion-producing rhetoric. Sowder notes that conversion, or the adoption of a new model of the self requires this sort of abandonment, or "unraveling of identity" (209).

35 For instance Whitman's claim in "Song of Myself" that "I will never again mention love or death inside a house, / And I swear I will never translate myself at all, only to him or her who privately stays with me in the open air" ( $L G 1867,89)$.

36 One is reminded of "The youngster and the red-faced girl" on the "bushy hill" which Whitman's speaker "peeringly" views in "Song of Myself" ( $L G 1867,31)$.

37 Whitman, Correspondence, 2:170. Interestingly, this letter is omitted from the exchange in The Letters of Anne Gilchrist and Walt Whitman.

38 This is of course not the first or last time that Whitman would be chided by a disciple for not maintaining in life the persona that he had built in Leaves. Both Richard Maurice Bucke and Horace Traubel had many such conflicts with Whitman-recorded mostly in Traubel's With Walt Whitman in Camden (9 vols., various publishers).

39 Ralph Waldo Emerson, "Friendship," Essays and Lectures, ed. Joel Porte (New York: Library of America, 1983), 341-342.

40 Ralph Waldo Emerson, "Self Reliance," Essays and Lectures, 259.

41 Beatrice had been studying medicine in Berne, Switzerland, had come home after some traumatic event, and then gone to Edinburgh to be an assistant to a female doctor and resume her studies. Her body was found in a field outside of the city, badly decomposed. Anne hid the real cause of death in letters to friends (including Walt), saying that Beatrice had been killed by accidental exposure to too much ether (Alcaro, 210-213).

42 Walt Whitman, Leaves of Grass (Philadelphia: David McKay, 1891-92), 396. An electronic facsimile and transcription of this edition is available online from The Walt Whitman Archive, ed. Ed Folsom and Ken Price, www.whitmanarchive.org. 